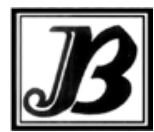

J. Bio-Sci. 27: 69-81, 2019

ISSN 1023-8654

http://www.banglajol.info/index.php/JBS/index

DOI: https://doi.org/10.3329/jbs.v27i0.44672

\title{
DOCUMENTATION OF WILD EDIBLE MINOR FRUITS USED BY THE LOCAL PEOPLE OF BARISHAL, BANGLADESH WITH EMPHASIS ON TRADITIONAL MEDICINAL VALUES
}

\author{
ATM Rafiqul Islam ${ }^{1}$, SK Das ${ }^{1}$ MF Alam ${ }^{2}$ and AHMM Rahman ${ }^{3 *}$ \\ ${ }^{1}$ Department of Botany, Faculty of Bio-Sciences, University of Barishal, Barishal-8200, Bangladesh \\ 2Institute of Biological Sciences, University of Rajshahi, Rajshahi-6205, Bangladesh \\ ${ }^{3}$ Department of Botany, University of Rajshahi, Rajshahi-6205, Bangladesh
}

\begin{abstract}
The present investigation has been conducted for identification, documentation and exploration of wild edible fruit producing plant species and traditional medicinal uses of these fruits by local peoples from 14 villages of 7 upazila of Barisal district. A total of 43 wild edible fruit producing plant species belonging to 33 genera under 23 families have been recorded. For each species scientific, local and English name, habit, fruiting time and traditional medicinal uses of these fruits have been presented. Among the identified species Polyalthia suberosa Roxb., Flacourtia indica (Burm.f.) Merr., Flacourtia jangomas (Lour.) Rausch., Dimocarpus longan Lour., were recorded from the study area as new findings. Moreover, Flacourtia indica (Burm.f.) Merr., Flacourtia jangomas (Lour.) Rausch., Dimocarpus longan Lour., Polyalthia suberosa Roxb., Syzygium jambos L., Lepisanthes senegalensis (Poir.) Leenhouts., Lepisanthes rubiginosa (Roxb.) Leenh., were identified as rare species and currently they are endangered in their natural habitat. The findings of the research indicate that, there has a great pharmacological value of wild edible fruits for discovering new drugs and medicines.
\end{abstract}

Key words: Drug discovery, Medicinal values, Wild edible fruits

\section{Introduction}

Rural peoples are mostly dependent on Wild Edible Fruits (WEFs) in most cases to fulfill their nutritional requirements. They are not only depends either for nutritional needs or for daily food securities but also depends for their daily health care treatments as medicinal purposes on Wild Edible Fruits. This wild edible fruits significantly influences their livelihood and food security. WEFs play a vital role by providing an important safety net to the rural poor people by means of dietary supplement or an important component of coping strategies as a form of survival at the times of food scarcity or shortage periods such as during famine and war and act as emergency food in times of drought or other crises. The use of WEFs as a source of food, medicine and nutritional supplement is not new but since ancient times and still are widely consumed by many people in rural areas, tribal and indigenous communities (Nahar et al. 1990).

WEFs can be defined as those fruits that are edible to human and produced in plants including native and introduced species that grow spontaneously in self-maintaining populations in natural or semi-natural ecosystems and can exist independently without any human interventions such as without being cultivation or domestication. WEFs have a great nutritional and medicinal value and considered as a good source of vitamins and minerals (micronutrients) such as copper, zinc, iron, manganese, magnesium etc and certain

*Author for correspondence: drrahmanahmm@ru.ac.bd 
hormones in addition to protein and energy; which all are essential for human body. Such even in some cases, many of these wild fruits contain richer nutritional values and mineral contents than that of commercial fruits (Nahar et al. 1990, Akubugwo et al. 2007, Seal et al. 2014).

Like other many developing countries in the world, millions of children and women of Bangladesh have been suffering from one or more forms of malnutrition problems such as low birth weight, wasting, stunting, underweight, Vitamin A deficiencies, iodine deficiency disorders and anaemia. Most of the children and women are poor rural inhabitants. The malnutrition problems in Bangladesh are ranked highest position in the world. The deficiencies of energy, vitamins, and minerals especially iron and folic acids are the main causes of this malnutrition (UNICEF 2009).

Since a considerable number of the people of Bangladesh are poor and live in rural areas, so, they are not able to buy commercial fruits due to its high price and unavailability in rural area. In this case, WEFs can play a vital role by providing essential mineral and nutrients among these peoples. But in the current time, these wild fruits producing plants are amazingly decreasing and further under threat, such even some of these are in extinct stage due to over exploitation and various pressure of anthropogenic activities such as cutting of forest and jungle. So, it is essential to conserve and proper take care of these plants.

Barisal is a division of Bangladesh located in the south central part of the country was composed of an amalgamation of marshlands formed by the merging of islands brought into existence and built up by alluvial soils washed down the great channels of the combined Brahmaputra-Ganges-Meghna river systems and makes it fertile. Moreover, this area provides different types of natural and semi-natural habitats and ecosystems including wetland, char land, riparian, scrub jungles, fallow lands etc. Which offer a large extent diversity of WEFs in Barisal region probably its fertile land containing alluvial soils and that play an important role in the local community by providing essential mineral and nutrients elements and in primary health care system. But unfortunately, there is no authentic data regarding documentation of WEFs in these areas. Many investigators were accomplished work on wild edible fruits at different areas in India and other parts of the world (Murugkar and Subbulakshmi 2005, Mengistu and Hager 2009, Hazarika and Nautiyal 2012, Mahapatra et al. 2012). But so far there is no such type of work has been previously reported in Bangladesh. In the present study, we conducted the investigation on WEFs in Barisal region to explore its nutritional and medicinal values. Therefore, the main objectives of the present study are identification, documentation and exploration of wild edible fruits consumed by local inhabitants of Barisal region.

\section{Materials and Methods}

The study area was composed of 14 villages of 7 upazila namely Bakerganj, Babuganj, Banaripara, Wazirpur, Agailjhara, Gaurnadi and Mehendiganj of Barisal district, Bangladesh (Fig. 1). Barisal district is bounded by Madaripur, Shariatpur, Chandpur and Lakshmipur districts on the north, Patuakhali, Barguna and Jhalakathi districts on the south, Bhola and Lakshmipur districts on the east, Jhalakathi, Pirojpur and Gopalganj districts on the west. It lies between $22^{\circ} 27^{\prime}$ and $22^{\circ} 52^{\prime}$ north latitudes and between $90^{\circ} 01^{\prime}$ and $90^{\circ} 43^{\prime}$ east longitudes (BBS 2013). 


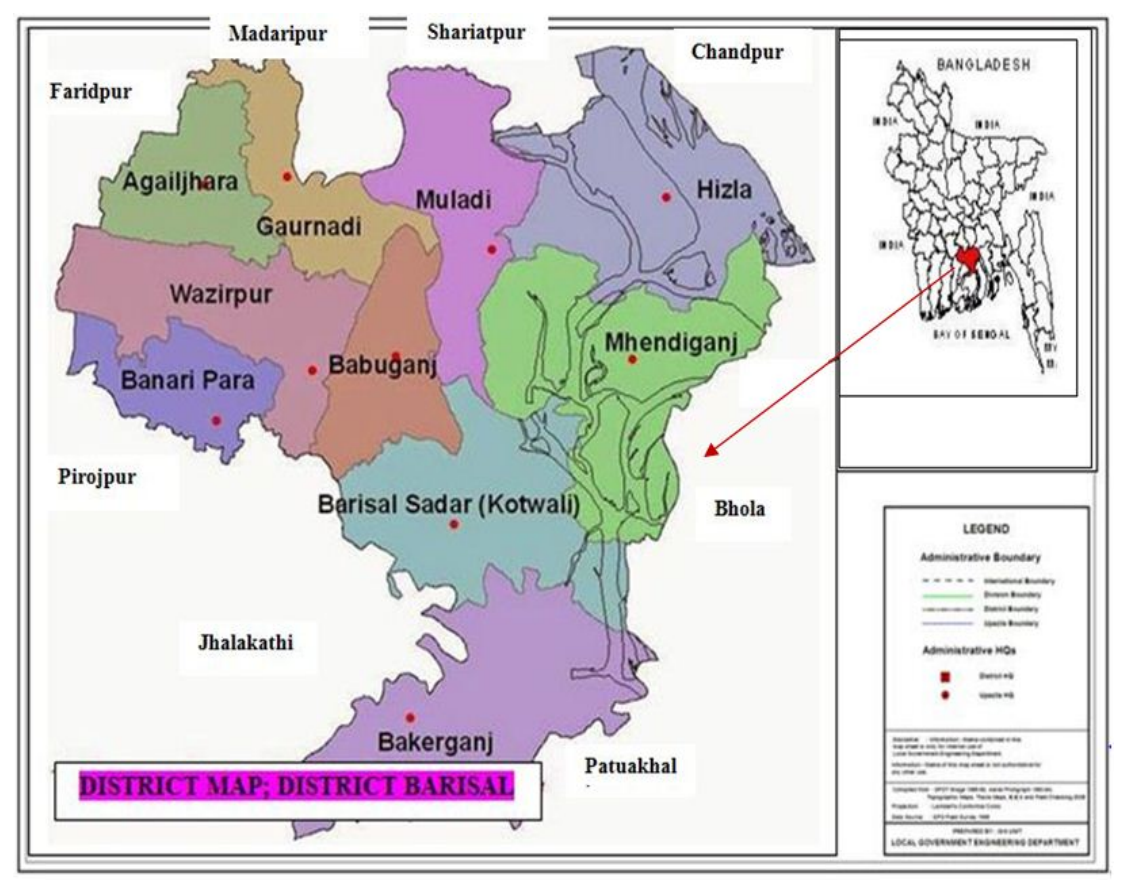

Fig. 1. Geographical map of Barishal district.

The present investigations were conducted by data collection through several field trips during June 2017 to July 2018 in different seasons such as summer, monsoon, winter and spring. A total of 70 peoples were interviewed who are largely comprised of old ages villagers including farmers and shepherds through field interview, group interview by adopting open-ended and semi-structured question techniques (Martin 1995). Questionnaires for collecting information on local name, habit, fruiting time and uses as medicine were prepared. Demographic characteristics of the particulars and local name were noted at the time of meeting them. Consumption methods and applications of wild fruit parts as folk medicine were also documented. The data on documentation, identification, exploration and traditional medicinal uses of wild edible fruits were collected. Available photographs from internet were shown to them for local identification. The collected specimens were identified studying taxonomic books and booklets from the library of Barisal University and Rajshahi University. The collected materials were identified and described up to species with the help of different books and journals; (Hooker 1877, Prain 1903, Kirtikar and Basu 1987, Siddiqui et al. 2007, Ahmed et al. 2008-2009). For the current name and up to date nomenclature Huq (1986), and Pasha and Uddin (2013) were consulted.

\section{Results and Discussion}

The present study conducted at 14 villages of 7 upazila in Barishal district have been documented a total of 43 species, belonging to 33 genera and 23 families of wild edible fruits producing plants that are being used by local peoples. Out of these 43 plant species 36 are dicotyledons under 19 families, 7 are monocotyledons under 4 families (Table 1). The recorded species among the 23 families of the study area are most utilized species belong to Myrtaceae (5), Rosaceae and Arecaceae (4), Annonaceae, Moraceae and Sapindaceae 
(3), Anacardiaceae, Ebenaceae, Sapotaceae and Euphorbiaceae families represents 2 each. And the remaining 13 families are monotypic, viz., representing only by one species (Fig. 2). The primary information like botanical names, local names, English names, family, fruiting time, habit of plant have been mentioned in Table 1. In the present study about 43 wild edible fruits producing plant species have been enumerated, among them $2(5 \%)$ are herbs, $10(23 \%)$ are shrubs and $31(72 \%)$ are trees have identified based on their availability in the study area (Fig. 3).

Table1. List of wild edible minor fruits producing plant species in the study areas of Barishal district

\begin{tabular}{|c|c|c|c|c|c|c|}
\hline SI. No. & Scientific name & Local Name & English Name & Family & Habit & $\begin{array}{l}\text { Fruiting } \\
\text { seasons }\end{array}$ \\
\hline & \multicolumn{6}{|l|}{ Liliopsida (Monocots) } \\
\hline 1 & Borassus flabellifer $\mathrm{L}$. & Tal & Palmyra-palm & Arecaceae & Tree & $\begin{array}{l}\text { August- } \\
\text { October }\end{array}$ \\
\hline 2 & Calamus tenuis Roxb. & Bet phal & Cane & Arecaceae & Shrub & $\begin{array}{l}\text { February- } \\
\text { March }\end{array}$ \\
\hline 3 & Cocos nucifera L. & Narikel & Coconut & Arecaceae & Tree & $\begin{array}{l}\text { Throughout } \\
\text { the year }\end{array}$ \\
\hline 4 & Phoenix sylvestris L. & Khajur / Khejur & Wild Date Palm & Arecaceae & Tree & June-July \\
\hline 5 & Musa acuminata Colla. & Jonglikola & Wild Banana & Musaceae & Herb & $\begin{array}{l}\text { Throughout } \\
\text { the year }\end{array}$ \\
\hline 6 & $\begin{array}{l}\text { Pandanus tectorius Parkinson } \\
\text { ex Du Roi. }\end{array}$ & Keya-kantaphal & Screw pine & Pandanaceae & Shrub & $\begin{array}{l}\text { September- } \\
\text { January }\end{array}$ \\
\hline 7 & Typha elephantina Roxb. & Hogla & Elephant grass & Typhaceae & Shrub & $\begin{array}{l}\text { July- } \\
\text { September }\end{array}$ \\
\hline & \multicolumn{6}{|l|}{ Magnoliopsida (Dicots) } \\
\hline 8 & Spondias dulcis L. & Bilatiamra & Jew Plum & Anacardiaceae & Tree & $\begin{array}{l}\text { August- } \\
\text { September }\end{array}$ \\
\hline 9 & Spondias pinnata (L. f.) Kurz. & Deshi-amra & Hog-plum & Anacardiaceae & Tree & $\begin{array}{l}\text { August- } \\
\text { September. }\end{array}$ \\
\hline 10 & Annona reticulata L. & Ata & Bullock's heart & Annonaceae & Tree & $\begin{array}{l}\text { December - } \\
\text { May }\end{array}$ \\
\hline 11 & Annonas quamosa $\mathrm{L}$. & Sharifa & Custard Apple & Annonaceae & Tree & $\begin{array}{l}\text { August- } \\
\text { October }\end{array}$ \\
\hline 12 & Polyalthia suberosa Roxb. & Hamjam/ Murmuri & Polyalthia & Annonaceae & Shrub & $\begin{array}{l}\text { February- } \\
\text { March }\end{array}$ \\
\hline 13 & Carissa carandas L. & Karamcha & Karaunda & Apocynaceae & Shrub & February-April \\
\hline 14 & Averrhoa carambola L. & Kamranga & $\begin{array}{l}\text { Carambola } \\
\text { Apple }\end{array}$ & Averrhoaceae & Tree & $\begin{array}{l}\text { Throughout } \\
\text { the year }\end{array}$ \\
\hline 15 & Tamarindus indica L. & Tentul & Tamarind & Caesalpiniaceae & Tree & February-May \\
\hline 16 & Garcinia cowa Roxb. & Kau / Cowa & $\begin{array}{l}\text { Brindal } \\
\text { berry/Cow Tree }\end{array}$ & Clusiaceae & Tree & June-August \\
\hline 17 & Terminalia catappa L. & Kath Badam & Indian Almond & Combretaceae & Tree & $\begin{array}{l}\text { June- } \\
\text { September }\end{array}$ \\
\hline 18 & Dillenia indica L. & Chalta/ Chalita & Elephant apple & Dilleniaceae & Tree & $\begin{array}{l}\text { August- } \\
\text { November }\end{array}$ \\
\hline
\end{tabular}




\begin{tabular}{|c|c|c|c|c|c|c|}
\hline & & & & & & Contd. \\
\hline 19 & Diospyros blancoi A. DC. & Belati gab & Velvet apple & Ebenaceae & Tree & June-August \\
\hline 20 & $\begin{array}{l}\text { Diospyros malabarica (Desr.) } \\
\text { Kostel }\end{array}$ & Deshi gab & Malabar ebony & Ebenaceae & Tree & June-July \\
\hline 21 & $\begin{array}{l}\text { Flacourtia indica (Burm.f.) } \\
\text { Merr. }\end{array}$ & Katabohori/Boichi & $\begin{array}{l}\text { Governor's } \\
\text { plum }\end{array}$ & Flacourtiaceae & Shrub & $\begin{array}{l}\text { November- } \\
\text { March }\end{array}$ \\
\hline 22 & $\begin{array}{l}\text { Artocarpus lacucha Buch- } \\
\text { Ham. }\end{array}$ & Dewa/Deophal & Monkey jack & Moraceae & Tree & May-July \\
\hline 23 & Ficus carica L. & Dumur & Common fig & Moraceae & Tree & May-July \\
\hline 24 & Ficus racemosa L. & Jagadumur & Cluster fig & Moraceae & Tree & May-July \\
\hline 25 & Pisidium guajava (L.) Bat. & Piyara & Guava & Myrtaceae & Tree & $\begin{array}{l}\text { June- } \\
\text { September }\end{array}$ \\
\hline 26 & Syzygium cumini (L.) Skeel. & Jam/Kalojam & Blackberry & Myrtaceae & Tree & May-June \\
\hline 27 & $\begin{array}{l}\text { Syzygium fruticosum (Roxb.) } \\
\text { DC. }\end{array}$ & Lohagora & Lilly Pilly & Myrtaceae & Tree & May-June \\
\hline 28 & Syzygium jambos L. & Golapjam & Rose Apple & Myrtaceae & Shrub & April-August \\
\hline 29 & $\begin{array}{l}\text { Syzygium samarangense } \\
\text { (Blume) Merr. \& L.M. Perry }\end{array}$ & Jamrul & Wax Apple & Myrtaceae & Tree & May-June \\
\hline 30 & Zizyphus rugosa Lamk. & Janglikul & Jackal Jujube & Rhamnaceae & Shrub & May-July \\
\hline 31 & Aegle marmelos (L.) Corr. & Bel & Wood Apple & Rutaceae & Tree & March-May \\
\hline 32 & Citrus grandis (L.) Osbeck. & Jambura & Pummelo & Rutaceae & Tree & $\begin{array}{l}\text { August- } \\
\text { September }\end{array}$ \\
\hline 33 & $\begin{array}{l}\text { Glycosmis pentaphylla (Retz.) } \\
\text { A. DC. }\end{array}$ & Atuli & $\begin{array}{l}\text { Toothbrush } \\
\text { Plant }\end{array}$ & Rutaceae & Shrub & April-June \\
\hline 34 & $\begin{array}{l}\text { Flacourtia jangomas (Lour.) } \\
\text { Rausch. }\end{array}$ & Paniala/payela & $\begin{array}{l}\text { Many spiked } \\
\text { Flacortia }\end{array}$ & Salicaceae & Tree & $\begin{array}{l}\text { August- } \\
\text { October }\end{array}$ \\
\hline 35 & Dimocarpus longan Lour. & Kath Litchi/Ashphal & Longan & Sapindaceae & Tree & $\begin{array}{l}\text { August - } \\
\text { September }\end{array}$ \\
\hline 36 & $\begin{array}{l}\text { Lepisanthes senegalensis } \\
\text { (Poir.) Leenhouts }\end{array}$ & Amjam koruna & Not Known & Sapindaceae & Shrub & May-June \\
\hline 37 & $\begin{array}{l}\text { Lepisanthes rubiginosa } \\
\text { (Roxb.) Leenh. }\end{array}$ & Chagalnadi/Chagalkurkuri & Not Known & Sapindaceae & Tree & May-June \\
\hline 38 & Mimusops elengi L. & Bakul & Elengi & Sapotaceae & Tree & $\begin{array}{l}\text { October- } \\
\text { December }\end{array}$ \\
\hline 39 & Manilkara zapota L. & Shopeda & Sapodilla & Sapotaceae & Tree & $\begin{array}{l}\text { September - } \\
\text { January }\end{array}$ \\
\hline 40 & Limonia acidissima L. & Kodbel & Wood Apple & Rutaceae & Tree & April-June \\
\hline 41 & Physalis minima L. & Foska begun & $\begin{array}{l}\text { Native } \\
\text { gooseberry }\end{array}$ & Solanaceae & Herb & March-April \\
\hline 42 & Phyllanthus acidus (L.) Skeels. & Neur/Arboroi & $\begin{array}{l}\text { Star } \\
\text { Gooseberry }\end{array}$ & Euphorbiaceae & Tree & June-July \\
\hline 43 & Phyllanthus emblica L. & Amloki & $\begin{array}{l}\text { Indian } \\
\text { Gooseberry }\end{array}$ & Euphorbiaceae & Tree & $\begin{array}{l}\text { October- } \\
\text { December }\end{array}$ \\
\hline
\end{tabular}




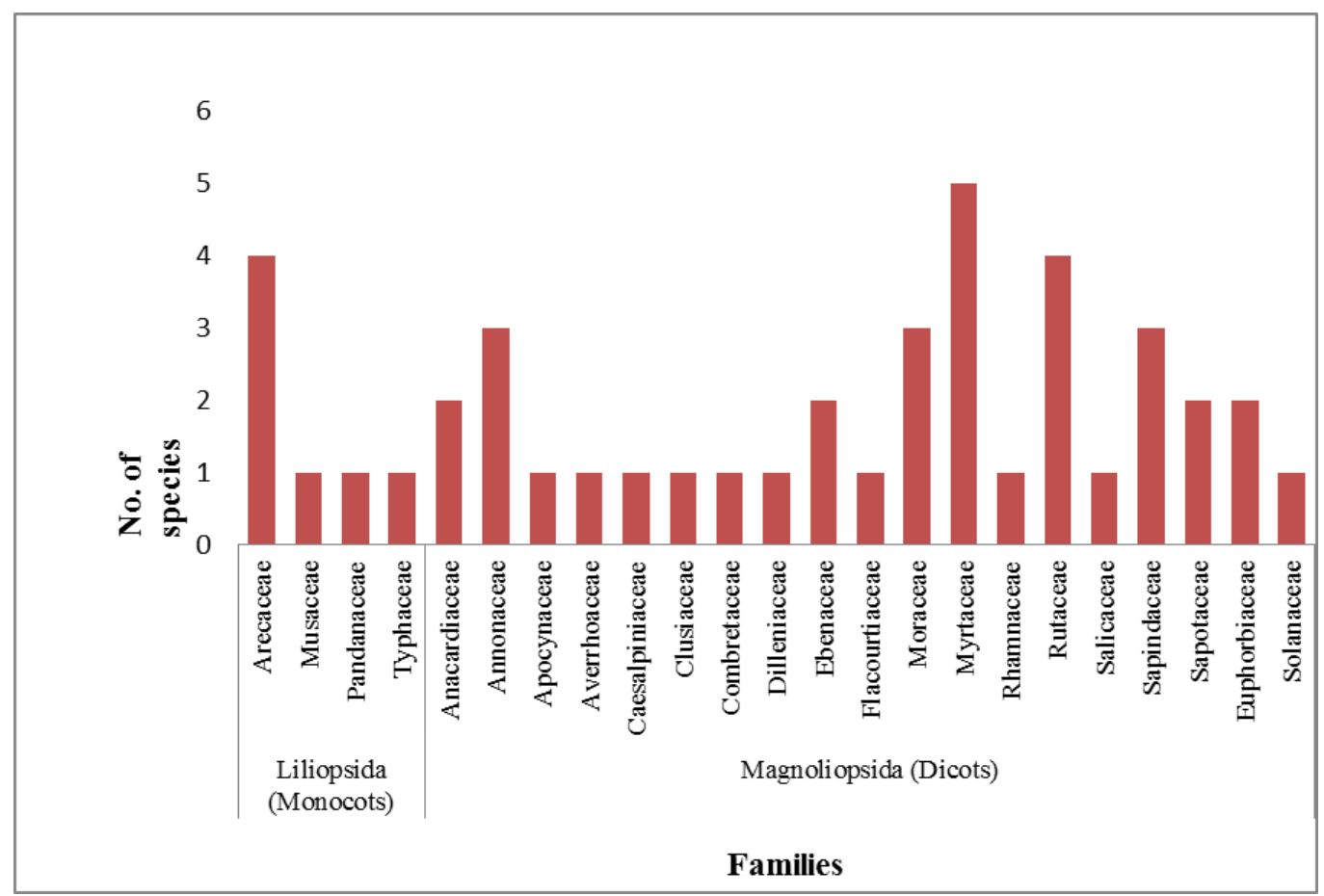

Fig. 2. Recorded wild edible fruit producing plant species among different families.

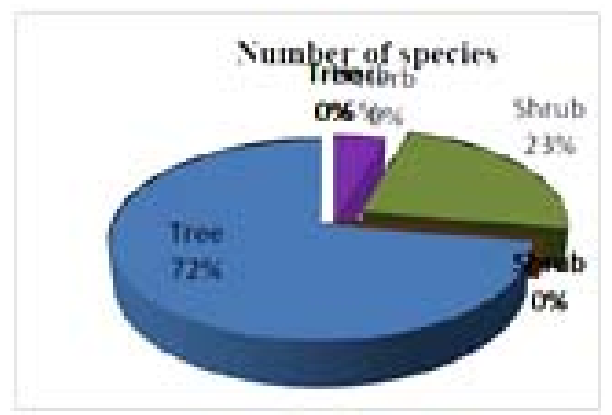

Fig. 3. Recorded plant types in the study area.

Use of wild fruits as folk medicine by the local peoples: Investigation of traditional medicinal uses of wild edible fruits by the local peoples of the study areas were recorded (Table 2). A total of 43 plant species under 33 genera of 23 families have been documented which are used for the treatment of various diseases are listed below: 
Table 2. Traditional medicinal uses of wild edible fruits by local peoples of Barisal district

\begin{tabular}{|c|c|c|}
\hline $\begin{array}{l}\text { Sl. } \\
\text { No. }\end{array}$ & Scientific name & Medicinal uses by local peoples \\
\hline & Liliopsida (Monocots) & \\
\hline 1 & Borassus flabellifer $\mathrm{L}$. & Fruits are eaten as a treatment for hiccough, nausea and skin disease \\
\hline 2 & Calamus tenuis Roxb. & Fruits are eaten as a treatment for abdominal pain \\
\hline 3 & Cocos nucifera L. & $\begin{array}{l}\text { Fruits are eaten as a treatment for diarrhoea and dysentery; useful in fever and } \\
\text { urinary disorders }\end{array}$ \\
\hline 4 & Phoenix sylvestris L. & $\begin{array}{l}\text { Fruits are eaten as treatment for heart complaints, abdominal complaints, fevers, } \\
\text { vomiting and loss of consciousness }\end{array}$ \\
\hline 5 & Musa acuminata Colla. & Unripe fruits are eaten as a treatment for diarrhoea \\
\hline 6 & $\begin{array}{l}\text { Pandanus tectorius Parkinson ex } \\
\text { Du Roi. }\end{array}$ & $\begin{array}{l}\text { Fruits are eaten as a treatment for headache, cold/flu, wounds, ulcers, hepatitis, } \\
\text { smallpox, leprosy, syphilis etc. }\end{array}$ \\
\hline \multirow[t]{2}{*}{7} & Typha elephantina Roxb. & Ripe fruits are used in emergency as medicated absorbent to wounds and ulcers \\
\hline & Magnoliopsida (Dicots) & \\
\hline 8 & Spondias dulcis L. & $\begin{array}{l}\text { Fruit juice is eaten for the treatment of high blood pressure. The young fruit is used } \\
\text { to treat stomach trouble and to aid a woman in labour }\end{array}$ \\
\hline 9 & Spondias pinnata (L. f.) Kurz. & $\begin{array}{l}\text { The unripe fruit is eaten for the treatment of rheumatism and sore throat. Ripe fruit is } \\
\text { eaten for curing burning sensation }\end{array}$ \\
\hline 10 & Annona reticulata $\mathrm{L}$. & Unripe fruits are eaten as a treatment for dysentery, diarrhoea and intestinal worms \\
\hline 11 & Annonas quamosa L. & Ripe fruit is eaten for lessens burning sensation and sedative to the heart \\
\hline 12 & Polyalthia suberosa Roxb. & Ripe fruits are eaten as diuretic, soporific, and sedative \\
\hline 13 & Carissa carandas L. & The fruits are used as a remedy for biliousness \\
\hline 14 & Averrhoa carambola L. & $\begin{array}{l}\text { Fruits are eaten as a treatment for skin disorders and fevers, jaundice, bleeding } \\
\text { piles, use as a remedy for high blood pressure }\end{array}$ \\
\hline 15 & Tamarindus indica L. & $\begin{array}{l}\text { Uses as a household remedy for fever, dyspepsia, gastritis, dysentery and } \\
\text { diarrhoea, also uses as a remedy for high blood pressure }\end{array}$ \\
\hline 16 & Garcinia cowa Roxb. & $\begin{array}{l}\text { Fruits are eaten for the treatment of headache and sun-dried slices of the fruits are } \\
\text { used in dysentery }\end{array}$ \\
\hline 17 & Terminalia catappa L. & Fruits are eaten as a treatment for bronchitis \\
\hline 18 & Dillenia indica L. & Fruits are used in the treatment of diarrhoea, dysentery and burns \\
\hline 19 & Diospyros blancoi A. DC. & The juice of unripe fruit is used as a wash for wounds \\
\hline 20 & $\begin{array}{l}\text { Diospyros malabarica (Desr.) } \\
\text { Kostel }\end{array}$ & $\begin{array}{l}\text { Unripe fruits is used externally to heal sores and wounds, the seeds are used as a } \\
\text { treatment for diarrhoea and chronic dysentery }\end{array}$ \\
\hline 21 & Flacourtia indica (Burm.f.) Merr. & Fruits are given in the treatment of jaundice and enlarged spleen \\
\hline 22 & Artocarpus lacucha Buch-Ham. & Fruits juice are applied externally to boils, pimples, cuts and wounds \\
\hline 23 & Ficus carica L. & $\begin{array}{l}\text { Unripe fruits are eaten for colic treatment and also for treatment of indigestion and } \\
\text { loss of appetite }\end{array}$ \\
\hline
\end{tabular}


Contd.

\begin{tabular}{|c|c|c|}
\hline 24 & Ficus racemosa L. & $\begin{array}{l}\text { Fruits are given in the treatment of bronchitis, dry cough, diseases of kidney and } \\
\text { spleen. Fruits are also used for rheumatic pain }\end{array}$ \\
\hline 25 & Pisidium guajava (L.) Bat. & Fruits are given in the treatment of diarrhoea and dysentery \\
\hline 26 & Syzygium cumini (L.) Skeel. & $\begin{array}{l}\text { Fruits, especially seeds are used for treatment for diabetes, Jaundice. Fruits are } \\
\text { eaten as a tonic to the liver, stomachic, carminative and diuretic }\end{array}$ \\
\hline 27 & Syzygium fruticosum (Roxb.) DC. & Seeds are eaten for treatment of diabetes and Jaundice \\
\hline 28 & Syzygium jambos L. & $\begin{array}{l}\text { Fruit is used as a tonic for the brain and liver. Seeds are eaten for the treatment of } \\
\text { diarrhoea, dysentery and catarrh }\end{array}$ \\
\hline 29 & $\begin{array}{l}\text { Syzygium samarangense (Blume) } \\
\text { Merr. \& L.M. Perry }\end{array}$ & Flowers and fruits are used to treat fevers and halt diarrhoea \\
\hline 30 & Zizyphus rugosa Lamk. & Fruits are often used for the treatment of menorrhagia \\
\hline 31 & Aegle marmelos (L.) Corr. & Unripe fruit is used in diarrhoea, dysentery and ripe fruit for constipation \\
\hline 32 & Citrus grandis (L.) Osbeck. & Used for the treatment of influenza, cough, catarrh and asthma \\
\hline 33 & $\begin{array}{l}\text { Glycosmis pentaphylla (Retz.) A. } \\
\text { DC. }\end{array}$ & Ripe fruits are given to treat diarrhoea, coughs, rheumatism, anaemia, and jaundice \\
\hline 34 & $\begin{array}{l}\text { Flacourtia jangomas (Lour.) } \\
\text { Rausch. }\end{array}$ & $\begin{array}{l}\text { Fruit endosperm is taken to maintain the proper function of kidney. Fruit is taken for } \\
\text { the remedy of entering fish thorn in throat }\end{array}$ \\
\hline 35 & Dimocarpus longan Lour. & $\begin{array}{l}\text { Fruit is given as a stomachic, febrifuge and vermifuge, and also as an antidote for } \\
\text { poison }\end{array}$ \\
\hline 36 & $\begin{array}{l}\text { Lepisanthes senegalensis (Poir.) } \\
\text { Leenhouts }\end{array}$ & Fruits are eaten for the treatment of diarrhoea and dysentery \\
\hline 37 & $\begin{array}{l}\text { Lepisanthes rubiginosa (Roxb.) } \\
\text { Leenh. }\end{array}$ & Fruits are eaten for the treatment of diarrhea, dysentery and Jaundice \\
\hline 38 & Mimusops elengi L. & $\begin{array}{l}\text { Fruits are used in dental ailments such as bleeding gums, pyorrhea, dental caries, } \\
\text { and loose teeth }\end{array}$ \\
\hline 39 & Manilkara zapota L. & The fruit is eaten as a remedy for indigestion and diarrhoea \\
\hline 40 & Limonia acidissima L. & $\begin{array}{l}\text { Unripe fruit is used in the treatment of diarrhoea and dysentery. Ripe fruits are used } \\
\text { mainly as a liver tonic to stimulate the digestive system }\end{array}$ \\
\hline 41 & Physalis minima L. & $\begin{array}{l}\text { Fruits is taken to cure digestive and intestinal problems, and is externally applied to } \\
\text { treat various skin problems such as sores, boils and cuts }\end{array}$ \\
\hline 42 & Phyllanthus acidus (L.) Skeels. & $\begin{array}{l}\text { Fruits are used in bronchitis, biliousness, urinary concretions and piles; useful in } \\
\text { thirst, vomiting and constipation }\end{array}$ \\
\hline 43 & Phyllanthus emblica L. & $\begin{array}{l}\text { Fruits are eaten in the treatment of vomiting and burning urination, diseases of the } \\
\text { heart and liver, piles, stops nasal haemorrhage. It gives to the children's for } \\
\text { promoting resistance to cough and cold; used as a hair tonic. Dried fruits are useful } \\
\text { in haemorrhoids, diarrhoea, dysentery, anaemia, jaundice and dyspepsia. The fruits } \\
\text { are also used in curing of insomnia, skin problems, gall pain, leucorrhoea and } \\
\text { tympanites. }\end{array}$ \\
\hline
\end{tabular}


The current availability status of wild edible fruits producing species in their natural habitat of the study area was enumerated. Among the identified 43 plant species under 33 genera of 23 families, 1 species Flacourtia indica (Burm.f.) Merr. is in critically endangered situation, 5 species namely Spondias pinnata (L.f.) Kurz, Syzygium jambos L., Dimocarpus longan Lour., Lepisanthes senegalensis (Poir.) Leenhouts., Lepisanthes rubiginosa (Roxb.) Leenh., are in endangered situation, 8 species are in vulnerable situation and remaining 29 species are in available. List of the current availability status of wild edible fruits plant species in the study areas of Barisal district are given bellow:

Table 3. List of the current availability status of wild edible fruits plant species in the study area of Barishal district

\begin{tabular}{|c|c|c|c|c|c|c|}
\hline $\begin{array}{l}\text { Sl. } \\
\text { No. }\end{array}$ & Scientific name & Local name & Available & Vulnerable & Endangered & $\begin{array}{l}\text { Critically } \\
\text { endangered }\end{array}$ \\
\hline & Liliopsida (Monocots) & & & & & \\
\hline 1 & Borassus flabellifer $\mathrm{L}$. & Tal & $\mathrm{P}$ & - & - & - \\
\hline 2 & Calamus tenuis Roxb. & Bet phal & - & $P$ & - & - \\
\hline 3 & Cocos nucifera L. & Narikel & $P$ & - & - & - \\
\hline 4 & Phoenix sylvestris L. & Khajur / Khejur & $P$ & - & - & - \\
\hline 5 & Musa acuminata Colla. & Jonglikola & $P$ & - & - & - \\
\hline 6 & $\begin{array}{l}\text { Pandanus tectorius } \\
\text { Parkinson ex Du Roi. }\end{array}$ & Keya-kantaphal & $P$ & - & - & - \\
\hline \multirow[t]{2}{*}{7} & Typha elephantina Roxb. & Hogla & $P$ & - & - & - \\
\hline & Magnoliopsida (Dicots) & & & & & \\
\hline 8 & Spondias dulcis L. & Bilatiamra & $\mathrm{P}$ & - & - & - \\
\hline 9 & $\begin{array}{l}\text { Spondias pinnata (L. f.) } \\
\text { Kurz. }\end{array}$ & Deshi-amra & - & - & $P$ & - \\
\hline 10 & Annona reticulata $\mathrm{L}$. & Ata & $\mathrm{P}$ & - & - & - \\
\hline 11 & Annona squamosal L. & Sharifa & $P$ & - & - & - \\
\hline 12 & $\begin{array}{l}\text { Polyalthia suberosa } \\
\text { Roxb. }\end{array}$ & Hamjam/ Murmuri & - & $P$ & - & - \\
\hline 13 & Carissa carandas L. & Karamcha & - & $\mathrm{P}$ & - & - \\
\hline 14 & Averrhoa carambola L. & Kamranga & $\mathrm{P}$ & - & - & - \\
\hline 15 & Tamarindus indica L. & Tentul & $\mathrm{P}$ & - & - & - \\
\hline 16 & Garcinia cowa Roxb. & Kau / Cowa & - & $\mathrm{P}$ & - & - \\
\hline 17 & Terminalia catappa L. & Kath Badam & $P$ & - & - & - \\
\hline 18 & Dillenia indica L. & Chalta/ Chalita & $\mathrm{P}$ & - & - & - \\
\hline 19 & Diospyros blancoi A. DC. & Belati gab & $\mathrm{P}$ & - & - & - \\
\hline 20 & $\begin{array}{l}\text { Diospyros malabarica } \\
\text { (Desr.) Kostel }\end{array}$ & Deshi gab & $\mathrm{P}$ & - & - & - \\
\hline 21 & $\begin{array}{l}\text { Flacourtia indica } \\
\text { (Burm.f.) Merr. }\end{array}$ & Katabohori/Boichi & - & - & - & $P$ \\
\hline
\end{tabular}




\begin{tabular}{|c|c|c|c|c|c|c|}
\hline 22 & $\begin{array}{l}\text { Artocarpus lacucha } \\
\text { Buch-Ham. }\end{array}$ & Dewa/Deophal & $P$ & - & - & - \\
\hline 23 & Ficus carica L. & Dumur & P & - & - & - \\
\hline 24 & Ficus racemosa L. & Jagadumur & $\mathrm{P}$ & - & - & - \\
\hline 25 & $\begin{array}{l}\text { Pisidium guajava (L.) } \\
\text { Bat. }\end{array}$ & Piyara & $\mathrm{P}$ & - & - & - \\
\hline 26 & $\begin{array}{l}\text { Syzygium cumini (L.) } \\
\text { Skeel. }\end{array}$ & Jam/Kalojam & $\mathrm{P}$ & - & - & - \\
\hline 27 & $\begin{array}{l}\text { Syzygium fruticosum } \\
\text { (Roxb.) DC. }\end{array}$ & Lohagora & - & $\mathrm{P}$ & - & - \\
\hline 28 & Syzygium jambos L. & Golapjam & - & - & P & - \\
\hline 29 & $\begin{array}{l}\text { Syzygium samarangense } \\
\text { (Blume) Merr. \& L.M. } \\
\text { Perry }\end{array}$ & Jamrul & $\mathrm{P}$ & - & - & - \\
\hline 30 & Zizyphus rugosa Lamk. & Janglikul & - & $\mathrm{P}$ & - & - \\
\hline 31 & $\begin{array}{l}\text { Aegle marmelos (L.) } \\
\text { Corr. }\end{array}$ & Bel & $\mathrm{P}$ & - & - & - \\
\hline 32 & $\begin{array}{l}\text { Citrus grandis (L.) } \\
\text { Osbeck. }\end{array}$ & Jambura & $\mathrm{P}$ & - & - & - \\
\hline 33 & $\begin{array}{l}\text { Glycosmis pentaphylla } \\
\text { (Retz.) A. DC. }\end{array}$ & Atuli & $\mathrm{P}$ & - & - & - \\
\hline 34 & $\begin{array}{l}\text { Flacourtia jangomas } \\
\text { (Lour.) Rausch. }\end{array}$ & Paniala/payela & - & $\mathrm{P}$ & - & - \\
\hline 35 & Dimocarpus longan Lour. & Kath Litchi/Ashphal & - & - & $P$ & - \\
\hline 36 & $\begin{array}{l}\text { Lepisanthes } \\
\text { senegalensis (Poir.) } \\
\text { Leenhouts }\end{array}$ & Amjam koruna & - & - & $P$ & - \\
\hline 37 & $\begin{array}{l}\text { Lepisanthes rubiginosa } \\
\text { (Roxb.) Leenh. }\end{array}$ & Chagalnadi/Chagalkurkuri & - & - & $\mathrm{P}$ & - \\
\hline 38 & Mimusops elengi L. & Bakul & - & $P$ & - & - \\
\hline 39 & Manilkara zapota L. & Shopeda & $\mathrm{P}$ & - & - & - \\
\hline 40 & Limonia acidissima L. & Kodbel & $\mathrm{P}$ & - & - & - \\
\hline 41 & Physalis minima L. & Foska begun & $\mathrm{P}$ & - & - & - \\
\hline 42 & $\begin{array}{l}\text { Phyllanthus acidus (L.) } \\
\text { Skeels. }\end{array}$ & Neur/Arboroi & $\mathrm{P}$ & - & - & - \\
\hline 43 & Phyllanthus emblica L. & Amloki & P & - & - & - \\
\hline
\end{tabular}

*' $P$ ' is the symbol of availability of wild edible fruits producing plant species in the study area

There are 43 wild edible fruits producing plant species belonging to 33 genera and 23 families were recorded. Among these 7 are monocots and 36 are dicots. Over the past two decades many researchers have been carried out several studies on edible fruits in Bangladesh (Kibria and Anik 2010, Sajib and Uddin 2013) but records on documentation and identification of wild edible fruits (WEFs) is limited and so far no such work has been previously reported in Bangladesh. The record of edible fruit plants of Bangladesh reported by Sajib and Uddin (2013). They reported 75 edible fruit producing plant species of 54 genera under 
37 families from Swandip of Chittagong, Rahman et al. (2009 a\&b) 15 and 28 species from Hatiya island, Uddin et al. (2002) reported 28 species from Noakhali, Laxmipur and Feni district, Hossain and Uddin (2005) 31 species from Chittagong district, Kibria and Anik (2010) reported 19 species from Domar upazilla of Nilphamari, Rana et al. (2009) reported 23 species from Chagalnaiya upazilla of Feni district. Besides this, Begum (2004) and Alam et al. (1996) reported 55 and 43 edible fruits species from the country. In comparison to the earlier records, the present records about WEFs are more informative and abundant. In the present study, some rare and important wild edible fruits species were recorded which was not recorded previously from other areas of the country. Polyalthia suberosa Roxb., Flacourtia indica (Burm.f.) Merr., Flacourtia jangomas (Lour.) Rausch., Dimocarpus longan Lour.,were recorded from the study area as new findings.

The investigation of traditional medicinal uses of the documented WEFs species by local people of the study area was also focused. The local peoples have traditionally been consumed of these WEFs from the ancient times. They are eaten these ripe and unripe fruits for the treatment of various diseases likediarrhea, dysentery, fevers, jaundice, bronchitis, dry cough, diabetes, anemia, vomiting, dyspepsia, headache, cold or flu, wounds, ulcers, hepatitis, smallpox, leprosy, syphilis etc. and curing many other diseases. Besides this, local peoples are also used this WEFS to treat stomach trouble, heart complaints, abdominal complaints, high blood pressure, treatment of indigestion and loss of appetite, diseases of kidney, treatment of menorrhagia, and to aid a woman in labour. A number of researchers of the country have earlier been nicely described ethno medicinal knowledge of wild edible plants used in primary healthcare system by local communities (Chowdhury et al. 2009, Rahman et al. 2013, Islam et al. 2014, Sajib and Bokhtear 2015).

The documented wild edible fruits species in the study were categorized into 4 types based on their current availability status in the habitat. Among the 43 plant species under 33 genera of 23 families, 1 species Flacourtia indica (Burm. F.) Merr., is in critically endangered situation, 5 species namely Spondias pinnata (L.f.) Kurz., Syzygium jambos L., Dimocarpus longan Lour., Lepisanthes senegalensis (Poir.) Leenhouts., Lepisanthes rubiginosa (Roxb.) Leenh., are in endangered situation, 8 species are in vulnerable situation and remaining 29 species are in available. The available 29 species were also found as both cultivated and wild. The wild longan species used to be listed as vulnerable on the IUCN Red list and the listing was upgraded to near threatened in 1998. Recent field data are inadequate for a contemporary IUCN assessment (IUCN1998).

\section{Conclusion}

The present study focuses on the inventory documentation of wild edible minor fruits producing plant species and traditional medicinal uses of these WEFs in Barisal district. As far as, this research work is first record regarding the documentation of wild edible minor fruits and their traditional medicinal uses by local peoples of Barisal district. This research describes about the diversity of wild edible fruits species in the region as well as the current availability status of the species. This research also signifies the medicinal values of these wild fruits species. The findings of the research indicate that, there has a great pharmacological value of wild edible fruits for discovering new drugs and medicines. The findings of the research also precautious about the current status of some wild edible fruits species are in threatened condition due to lack of proper conservations. The current status of WEFs plant species calls for an urgent need of research and development effort for its conservation both in situ and ex situ and sustainable utilization. So, the further research is necessary for finding the way of conservations techniques of these wild edible fruits species and determination and evaluation of their nutritive values and medicinal properties for demanding the excess nutritional requirements of vitamins and minerals as well as new drugs discoveries. 


\section{Acknowledgements}

The authors express their gratitude to the local peoples in the study area of Barisal district for their cooperation and help during the study. The authors are grateful to the University of Barisal for providing UGC funded financial support to complete this research work.

\section{References}

Ahmed ZU, Hasan MA, Begum ZNT, Khondker M, Kabir SMH, Ahmad M and Ahmed ATA (eds.) (2008-2009). Encyclopedia of Flora and Fauna of Bangladesh, Vol. 6-10. Angiosperms: Dicotyledons. Asiatic Society of Bangladesh, Dhaka.

Akubugwo IE, Obasi AN and Ginika SC (2007).Nutritional potential of the leaves and seeds of black nightshade Solanum nigrum L. var. virginicum from Afikpo-Nigeria. Pak. J. Nutr., 6 (4): 323-326.

Alam MK, Mohiuddin M and Basak SR (1996). Village trees of Bangladesh: diversity and economic aspects. Bangladesh J. Forst. Sci., 25(1\&2): 21-36.

BBS (2013). District Statistics 2011 Barishal. Statistics and Informatics Division (SID), Ministry of Planning, Government of the People's Republic of Bangladesh, Dhaka.

Begum M (2004). Edible fruits of Bangladesh. Asiatic Civil Military Press. Swamibagh, Dhaka-1100, pp.1-123.

Chowdhury MSH, Koike M, Muhammad N, Halim MA, Saha N and Kobayashi H (2009). Use of plants in healthcare: a traditional ethno-medicinal practice in rural areas of southeastern Bangladesh. International Journal of Biodiversity Science and Management, 5(1): 41-51.

Hossain MK and Uddin MS (2005). Poverty alleviation through domestication and popularization of minor fruits-a case study in Chittagong district, Bangladesh. 17 $7^{\text {th }}$ Commonwealth Forestry Conference, Colombo, Sri Lanka, pp.1-13.

Hazarika TK and Nautiyal BP (2012). Studies on wild edible fruits of Mizoram, India used as ethno-medicine. Genetic Resources and Crop Evolution, 59 (8): 1767-1776.

Huq AM (1986). Plant Names of Bangladesh. Bangladesh National Herbarium, BARC, Dhaka, Bangladesh.

Hooker JD (1875 reprint 1961). Flora of British India. Vol. 1-7. L. Reeve and Co. Ltd. London, UK.

Islam MK, Saha S, Mahmud I, Mohamad K, Awang K, Jamal Uddin S, Rahman MM and Shilpi JA (2014). An ethnobotanical study of medicinal plants used by tribal and native people of Madhupur forest area. Bangladesh. J Ethnopharmacol., 151(2): 921-30.

Kibria MG and Anik SI (2010). Homestead plant species diversity and its contribution to the household economy: a case study from northern part of Bangladesh. J. Forest Sci., 26(1): 9-15.

Kirtikar KR and Basu BD (1987). Indian Medicinal Plants. Vol. 1-4. Lalit Mohan Basu, Allahabad, Jayyed Press, New Delhi, India.

Martin GJ (1995). Ethnobotany. A methods manual. Chapman and Hall., London.

Mahapatra AK, Mishra S, Basak UC and Panda PC (2012). Nutrient analysis of some selected wild edible fruits of deciduous forests of India: an explorative study towards non-conventional bio-nutrition. Adv. J. Food Sci. Technol., 4(1): 15-21.

Mengistu $\mathrm{F}$ and Hager $\mathrm{H}$ (2009). Wild edible fruit cultural domain, informant species competence and preference in three districts of Amhara region, Ethiopia. Ethno-Botany Research and Applications, 6: 487-502.

Murugkar DA and Subbulakshmi G (2005). Nutritive values of wild edible fruits, berries, nuts, roots and spices consumed by the Khasi tribes of India. Ecology of Food and Nutrition, 44(3): 207-223. 
Nahar N, Rahman S and Mosiihuzzaman M (1990). Analysis of carbohydrates in seven edible fruits of Bangladesh. J. Sci. Food Agric, 51: 185-192.

Pasha MK and Uddin SB (2013). Dictionary of Plant Names of Bangladesh (Vascular Plants). Janokalyan Prokashani. Chittagong, Dhaka, Bangladesh.

Prain D (1963). Bengal Plants. Vol. 1-2. Botanical Survey of India. Calcutta, India.

Rahman ML, Mannan MA, Hasanuzzaman M and Islam MK (2009). Fruit diversity related household characteristics in a selected island of Bangladesh. American-Eurasian J. Sci. Res., 4(3): 128-136.

Rahman ML, Hasanuzzaman M and Islam MK (2009). Fruit distribution and diversity in the homestead of a southern island of Bangladesh. Adv. Biol. Res., 3(5-6): 208-214.

Rahman AHMM, Sultana N, Islam AKMR and Zaman ATMN (2013). Study of medical ethno-botany at the village genda under Savar upazilla of district Dhaka, Bangladesh. Journal of Medicinal Plants Studies, 1(5): 72-86.

Rahman AHMM, Masum GZH, Sharkar P and Sima SN (2013). Medicinal plant usage by traditional medical practitioners of rural villages in Chuadanga district, Bangladesh. International Journal of Biodiversity Science, Ecosystem Services and Management, 9(4): 330-338.

Rana MP, Akhter S and Sohel MSI (2009). Economics of the plant species used in homestead agroforestry of southern Bangladesh. J. Forest Sci., 25(1): 35-41.

Sajib NH and Bokhtear (2015). Ethnomedicinal study of plants in Hathajari, Chittagong, Bangladesh. Pertanika Journal of Tropical Agricultural Science, 38(2): 197-210.

Seal T, Pillai B and Chaudhuri K (2014).Nutritional potential of wild edible fruits, traditionally used by the local people of Meghalaya state in India. Indian Journal of Natural Products and Resources, 5(4): 359-364.

Sajib NH and Uddin SB (2013). Edible fruits of Swandip, Chittagong, Bangladesh. Jahangirnagar University J. Biol. Sci., 2(1): 135-142.

Siddiqui KU, Islam MA, Ahmed ZU, Begum ZNT, Hasan MA, Khondker MR, MM Kabir, SMH, Ahmad, MAhmed ATA, Rahman AKA and Haque EU (eds.) (2007). Encyclopedia of Flora and Fauna of Bangladesh, Vol. 11. Angiosperms: Monocotyledons. Asiatic Society of Bangladesh, Dhaka.

UNICEF (2009). Child and Maternal Nutrition in Bangladesh. https:/l www. unicef. org/ Bangladesh/ Child_and_Maternal_Nutrition (1).

Uddin, MS, Rahman MJ, Mannan MA, Begum SA, Rahman AFMF and Uddin MR (2002). Plant biodiversity in the homesteads of saline area of southeastern Bangladesh. Pak. J. Boil. Sci., 5(60): 710-714.

IUCN (1998). Dimocarpus longan. IUCN Red List of Threatened Species. doi:10.2305/IUCN.UK.1998.RLTS.T32399A9698234.en.

(Manuscript received on March 03, 2018 and revised on September 01, 2018) 